\title{
Twenty-five years of the Journal of Brand Management
}

\author{
Joachim Kernstock $^{1} \cdot$ Shaun M. Powell ${ }^{2}$
}

Published online: 1 October 2018

(c) Springer Nature Limited 2018

\begin{abstract}
Following an earlier historical review of the Journal of Brand Management, this 25-year commemorative commentary by the editors outlines a number of themes published during recent years. It also provides a discussion on corporate brand management during the same period.
\end{abstract}

Keywords Brand management - Research directions . Future research . Corporate brand management

\section{Introduction}

The Journal of Brand Management (JBM) was launched during 1993 and by the end of 2018 spans 25 Volumes containing 169 issues. As highlighted in a previous historical review of the Journal (Powell 2014), the vision, mission and ethos of the journal have always sought to provide a balanced and inclusive publishing platform for a broad spectrum of perspectives in the field. The breadth and depth of research remains evident today as indicated by some of the themes presented during the past few years (see Table 1), alongside Special Issue themes (see Table 2). In addition, Table 3 highlights the top manuscripts published during 2015-2016 based on citations in 2017.

Shaun M. Powell

spowell@uow.edu.au

1 Competence Centre for Brand Management, St. Gallen, Switzerland

2 School of Management, Operations and Marketing, Faculty of Business, University of Wollongong, Wollongong, NSW 2522, Australia
At this 25-year milestone, and for brevity, the editors take the opportunity to select and focus on one areas development which has continued to grow during recent years, namely corporate brand management.

\section{Corporate brand management-past 5 years and future perspectives}

In recent years, corporate brand management has remained a "primus inter pares" within research in brand management, due to the specific role of the corporate brand and its contribution for the leadership of a company. In an earlier Special Issue on "Corporate Brand Management-A leadership perspective" published in the JBM during 2013, Balmer (2013) proposed nine schools of thought, which had emerged in the development of strategic thinking in brand management up to that point. We use these schools of thought to underpin our discussion of subsequent developments since then. Finally, we add one additional school which has not been included in the previous nine schools and which we feel warrants adding, acknowledging some other recent developments namely: the co-creative school (see also Schmidt and Redler 2018).

The philosophical school relates to the importance of the corporate brand as an organisational-wide mindset. This perspective has been adopted by demanding a "purpose" orientation rather than "positioning" when thinking about brand management within an organisation (Jones 2012). By placing the role of the CEO in the context of corporate brand management, and connecting the concepts contribution to the leadership of a corporation, Stuart (2013) gives the philosophical school an anchor in the organisation. This perspective leads to the demand for "bridging brand understanding and management" for further research and management practice (Brexendorf et al. 2015). 
Table 1 Some key themes published in JBM 2015-2017. Source: Powell 2015, 2016, 2017

\begin{tabular}{l} 
Key themes \\
\hline $\begin{array}{l}\text { Online and digital branding; luxury branding; brand measurement; brand engagement; brand orientation; brand personality; brand } 22,23, \\
\text { experience; brand equity; rebranding; brand and line extensions; anti-branding; brand counterfeiting and protection; branding in } \\
\text { higher education; brand and product naming; city branding; corporate identity and branding }\end{array}$ \\
\hline
\end{tabular}

Table 2 JBM special issues (Jan 2014-Jan 2019)

\begin{tabular}{|c|c|c|c|c|}
\hline Special issue & Guest editors & Volume & Issue & Year \\
\hline Consumer brand relationships & Marc Fetscherin, Daniel Heinrich & 21 & 5 & 2014 \\
\hline Future challenges and opportunities in brand management & $\begin{array}{l}\text { Tim Oliver Brexendorf, Joachim Kernstock, Shaun } \\
\text { M Powell }\end{array}$ & 21 & 9 & 2014 \\
\hline Development and management of brands in China & Weifeng Chen, John M T Balmer & 22 & 3 & 2015 \\
\hline $\begin{array}{l}\text { Corporate heritage, corporate heritage brands, and } \\
\text { organisational heritage }\end{array}$ & John M T Balmer, Mario Burghausen & 22 & 5 & 2015 \\
\hline 17th International Corporate Identity Group (ICIG) symposium & John M T Balmer, Russell Abratt, Nicola Kleyn & 23 & 1 & 2016 \\
\hline Harnessing the power of brand and co-created innovation & Mark Uncles, Liem Viet Ngo & 24 & 4 & 2017 \\
\hline Brands that do Good & Stuart Roper, Ming Lim, Oriol Iglesias & 25 & 1 & 2018 \\
\hline Internal brand management & Rico Piehler, Debra Grace, Christoph Burmann & 25 & 3 & 2018 \\
\hline Luxury brand-building & Michel Gutsatz, Klaus Heine & 25 & 5 & 2018 \\
\hline CSR and brands (forthcoming) & Urša Golob, Klement Podnar & 26 & 1 & 2019 \\
\hline
\end{tabular}

The behavioural school relates to the influence on customer behaviour, i.e. purchasing behaviour or customer loyalty, and employee behaviour showing to be on-brand. This school connects the brand management discussion with the wide field of brand experience. In an outlook on brand experience, Schmitt et al. (2015) emphasise the proliferation of media and the changing role of the brand in consumption experiences. Still, the role of the brand in social media and digital platforms remains a relatively underdeveloped area of enquiry in brand management research, but one of rapidly growing interest and focus, as noted in Table 1.

The hybrid school relates to a brand-focussed organisational-wide philosophy and organisational behaviours. This school has been relatively neglected within discussions in this journal in recent years.

The cultural school relates to corporate culture or an organisational-wide culture. Historically there has been a relatively strong tradition of focusing on organisational culture along with its own research agenda. Recently there have also been research achievements in bridging this tradition with research on brand management. For example, in this journal a substantial effort has been made via research on corporate heritage and corporate heritage brands which relates to a strong instrumental view on heritage and corporate culture (Balmer and Burghausen 2015). Additionally, the increased traction of internal brand management and the role of the employee has been emphasised by several researches and documented as one of the strong research fields within brand management, as evidenced by the recent Special Issue listed in Table 2 (Piehler et al. 2018).

The performance school is associated with the improvement of corporate performance linked to the brand. There is a long history of discussion on brand equity in this journal which continues as noted in Table 1. However, when it comes to brand value a definite financial value appears limited to a corporate transaction process (Sinclair and Keller 2017).

The strategic school of brand management considers the corporate brand as a starting point of corporate strategy. This is a very self-confident view of brand management. Nevertheless, brand portfolio management and the development of brand architecture strategies are profound fundamentals of a corporate strategy, including for strategic corporate actions like mergers and acquisition, where brand management is not the only but remains one key element (Keller 2015).

The marketing school relates brand management to the marketing function of the corporation. This view has its origin in considering brand management as a part of product brand management. Within product brand management, our discipline has its roots related to the role of the brand in packaging. This field of brand management remains highly relevant both for brand management research and practice and continues to need rigorous research and comprehensive practical implementation (Bresciani and del Ponte 2017). 
Table 3 JBM most cited manuscripts 2017 (published 2015-2016)

\begin{tabular}{|c|c|c|c|c|}
\hline Title & Authors & $\begin{array}{l}\text { Publication } \\
\text { year }\end{array}$ & $\begin{array}{l}\text { Volume/ } \\
\text { issue }\end{array}$ & $\begin{array}{l}\text { Special } \\
\text { issue }\end{array}$ \\
\hline $\begin{array}{l}\text { 'You'll never tweet alone': Managing sports brands through } \\
\text { social media }\end{array}$ & $\begin{array}{l}\text { Parganas, Petros; Anagnostopoulos, } \\
\text { Christos; Chadwick, Simon }\end{array}$ & 2015 & $22 / 7$ & \\
\hline $\begin{array}{l}\text { An integrated model of customer-brand engagement: Drivers and } \\
\text { consequences }\end{array}$ & $\begin{array}{l}\text { France, Cassandra; Merrilees, Bill; } \\
\text { Miller, Dale }\end{array}$ & 2016 & $23 / 2$ & \\
\hline $\begin{array}{l}\text { Motivations to interact with brands on Facebook-Towards a } \\
\text { typology of consumer-brand interactions }\end{array}$ & $\begin{array}{l}\text { Azar, Salim L.; Machado, Joana Cesar; } \\
\text { Vacas-de-Carvalho, Leonor; Mendes, } \\
\text { Ana }\end{array}$ & 2016 & $23 / 2$ & \\
\hline A brand culture approach to Chinese cultural heritage brands & $\begin{array}{l}\text { Schroeder, Jonathan; Borgerson, Janet; } \\
\text { Wu, Zhiyan }\end{array}$ & 2015 & $22 / 3$ & SI \\
\hline $\begin{array}{l}\text { Two sides of a coin: Connecting corporate brand heritage to } \\
\text { consumers' corporate image heritage }\end{array}$ & $\begin{array}{l}\text { Rindell, Anne; Santos, Fernando Pinto; } \\
\text { de Lima, Ana Pinto }\end{array}$ & 2015 & $22 / 5$ & SI \\
\hline $\begin{array}{l}\text { Heritage branding orientation: The case of Ach. Brito and the } \\
\text { dynamics between corporate and product heritage brands }\end{array}$ & $\begin{array}{l}\text { Santos, Fernando Pinto; Burghausen, } \\
\text { Mario; Balmer, John M.T. }\end{array}$ & 2016 & $23 / 1$ & \\
\hline $\begin{array}{l}\text { Explicating corporate heritage, corporate heritage brands and } \\
\text { organisational heritage }\end{array}$ & Balmer, John M.T.; Burghausen, Mario & 2015 & $22 / 5$ & SI \\
\hline $\begin{array}{l}\text { Using social media to communicate employer brand identity: } \\
\text { The impact on corporate image and employer attractiveness }\end{array}$ & Kissel, Patrick; Büttgen, Marion & 2015 & $22 / 9$ & \\
\hline $\begin{array}{l}\text { China's brands, China's brand development strategies and } \\
\text { corporate brand communications in China }\end{array}$ & Balmer, John M.T.; Chen, Weifeng & 2015 & $22 / 3$ & SI \\
\hline $\begin{array}{l}\text { Corporate heritage brands in China. Consumer engagement with } \\
\text { China's most celebrated corporate heritage brand-Tong Ren } \\
\text { Tang }\end{array}$ & Balmer, John M.T.; Chen, Weifeng & 2015 & $22 / 3$ & SI \\
\hline $\begin{array}{l}\text { Kill it or keep it?: The weak brand retain-or-discard decision in } \\
\text { brand portfolio management }\end{array}$ & Shah, Purvi & 2015 & $22 / 2$ & \\
\hline $\begin{array}{l}\text { Building self-brand connections: Exploring brand stories through } \\
\text { a transmedia perspective }\end{array}$ & Granitz, Neil; Forman, Howard & 2015 & $22 / 1$ & \\
\hline $\begin{array}{l}\text { Brand anthropomorphism: Conceptualization, measurement, and } \\
\text { impact on brand personality and loyalty }\end{array}$ & $\begin{array}{l}\text { Guido, Gianluigi; Peluso, Alessandro } \\
\text { M. }\end{array}$ & 2015 & $22 / 1$ & \\
\hline $\begin{array}{l}\text { The impact of brand strength on satisfaction, loyalty and WOM: } \\
\text { An empirical examination in the higher education sector }\end{array}$ & Casidy, Riza; Wymer, Walter & 2015 & $22 / 2$ & \\
\hline
\end{tabular}

The omni-brands school relates to a philosophy and culture that focuses on an organisation's brand in their entirety. The omni-brands school reflects on a specific role of the brand for its business and the corporation, its structure and processes and defining its customer relationship. In this context "luxury brand management" might be highlighted as a specific example. In almost no other industry the brand management is the warranty for success and performance by creating a specific customer-brand and customer-corporation relationship. Luxury brand management is a concept, an industry and a very specific strategy at the same time (Kapferer 2015). The luxury industry might be an example for an industry where brand management really matters. In this regard, luxury brand management has ranked highly among important topics in this journal, in terms of interest by readers and by authors.

The corpore brands school focusses on the stakeholder orientation of the brand. It includes all perspectives of all schools above and builds on their achievements in research and management practice. The corporate brand management school especially builds on the contribution of the corporate brand to the leadership of the company (Balmer et al. 2013). This field still needs further development in research and implementation, and we very much encourage researchers, practitioners and managers to continue to do so, especially where they have access to top management discussion and insights.

Last, but not least, we add the co-creative school as an important avenue for future research in brand management. Connected to innovation processes and the blurring of boundaries between corporations and their stakeholders, we think the co-creative school has it own qualification. Future developments of brand management either in research or in management practice may well be driven by co-creation. This research stream could add to previous results of the other schools discussed above while not substituting them. It could be named the co-creation continuum (Ind et al. 2017). The co-creative school gives 
guidance to collaborative processes with customers, users or other stakeholders for an evolutionary development of the brand. However, the co-creation perspective is not without its risks, challenges or potential pitfalls for corporate brand management. It may be difficult to orchestrate, at least for some organisations, as indicated by Schmeltz and Kjeldsen (2018) via their case study of a well-known public organisation. This also brings into light once again the potential contribution of internal brand management. Hence, while in our view the co-creative school is a worthy avenue for future corporate brand management research and holds great promise, research will need to approach the topic rigorously and from a number of perspectives and contexts, to ensure adequate clarity is achieved in the area. The co-creation perspective may also provide hints to potential gaps perhaps in some of the other schools that might be worthy of investigation in the future.

\section{Conclusion}

We would like to round off this celebratory commentary by reaffirming our commitment as editors to continuing to ensure "the JBM remains an accessible vehicle for leading edge thinking and learning: a journal that continues to challenge the boundaries of our knowledge in brand strategy and management ... publishing profound, thoughtful, rigorous, well-written, high-quality, high impact and at times provocative papers to generate discussion, debate, fresh perspective and insight" (Brexendorf et al. 2012, pp. 255-256).

Acknowledgements The JBM Editors (Joachim Kernstock and Shaun M. Powell) wish to extend our thanks to the publishing teams at Palgrave Macmillan and Springer Nature for their ongoing support of the Journal. We also wish to acknowledge the following for their guidance and support: John M.T. Balmer-Consulting Editors Chairman (Brunel University, London, UK), Stephen A. GreyserDeputy Consulting Editors Chairman (Harvard Business School, Boston, USA), Kevin Lane Keller (Tuck School of Business, Dartmouth College, USA), Susan Fornier (Boston University, USA) and Klaus-Peter Weidmann (Leibniz University Hannover, Germany). We thank previous emeritus editors Tim Oliver Brexendorf, TC Melewar and Temi Abimbola, plus present and past editorial board members, Special Issue editors and book reviewers. We also wish to pass on our deep gratitude to the many JBM authors who have contributed and shared their analysis and latest thinking with the brand management and marketing communities, as well as the many blind peer reviewers who have selflessly volunteered their expertise and time over the past 25 years.

\section{References}

Azar, S.L., J.C. Machado, L. Vacas-de-Carvalho, and A. Mendes. 2016. Motivations to interact with brands on Facebook-
Towards a typology of consumer-brand interactions. Journal of Brand Management 23 (2): 153-178.

Balmer, J.M.T. 2013. Corporate brand orientation: What is it? What of it? Journal of Brand Management 20 (9): 723-744.

Balmer, J.M.T., T.O. Brexendorf, and J. Kernstock. 2013. Corporate brand management-A leadership perspective. Journal of Brand Management 20 (9): 717-722.

Balmer, J.M.T., and M. Burghausen. 2015. Explicating corporate heritage, corporate heritage brands and organisational heritage. Journal of Brand Management 22 (5): 364-384.

Balmer, J.M.T., and W. Chen. 2015a. China's brands, China's brand development strategies and corporate brand communications in China. Journal of Brand Management 22 (3): 175-193.

Balmer, J.M.T., and W. Chen. 2015b. Corporate heritage brands in China. Consumer engagement with China's most celebrated corporate heritage brand-Tong Ren Tang. Journal of Brand Management 22 (3): 194-210.

Bresciani, S., and P. del Ponte. 2017. New brand logo design: customers' preference for brand name and icon. Journal of Brand Management 24 (5): 375-390.

Brexendorf, T.O., J. Kernstock, and S.M. Powell. 2012. Editorial: Statement from the new editors. Journal of Brand Management 19 (4): 255-256.

Brexendorf, T.O., J. Kernstock, and S.M. Powell. 2015. Future challenges and opportunities in brand management: An introduction to a commemorative special issue. Journal of Brand Management 21 (9): 685-688.

Casidy, R., and W. Wymer. 2015. The impact of brand strength on satisfaction, loyalty and WOM: An empirical examination in the higher education sector. Journal of Brand Management 22 (2): $117-135$.

France, C., B. Merrilees, and D. Miller. 2016. An integrated model of customer-brand engagement: Drivers and consequences. Journal of Brand Management 23 (2): 119-136.

Granitz, N., and H. Forman. 2015. Building self-brand connections: Exploring brand stories through a transmedia perspective. Journal of Brand Management 22 (1): 38-59.

Guido, G., and A.M. Peluso. 2015. Brand anthropomorphism: Conceptualization, measurement, and impact on brand personality and loyalty. Journal of Brand Management 22 (1): 1-19.

Ind, N., I. Oriol, and S. Markovic. 2017. The co-creation continuum: from tactical market research to strategic collaborative innovation method. Journal of Brand Management 24 (4): 310-321.

Jones, R. 2012. Five ways branding is changing. Journal of Brand Management 20 (2): 77-79.

Kapferer, J.N. 2015. The future of luxury: Challenges and opportunities. Journal of Brand Management 21 (9): 716-726.

Keller, K.L. 2015. Designing and implementing brand architecture strategies. Journal of Brand Management 21 (9): 702-715.

Kissel, P., and M. Büttgen. 2015. Using social media to communicate employer brand identity: The impact on corporate image and employer attractiveness. Journal of Brand Management 22 (9): 755-777.

Parganas, P., C. Anagnostopoulos, and S. Chadwick. 2015. 'You'll never tweet alone': Managing sports brands through social media. Journal of Brand Management 22 (7): 551-568.

Piehler, R., D. Grace, and C. Burmann. 2018. Internal brand management: introduction to the special issue and directions for further research. Journal of Brand Management 25 (3): 197-201.

Powell, S.M. 2014. Twenty-one years of the journal of brand management: A commemorative review. Journal or Brand Management 21 (9): 689-701.

Powell, S.M. 2015. Journal of Brand Management-Year end review 2015. Journal of Brand Management 22 (9): 715-720. 
Powell, S.M. 2016. Journal of Brand Management-Year end review 2016. Journal of Brand Management 23 (6): 601-611.

Powell, S.M. 2017. Journal of Brand Management-Year end review 2017. Journal of Brand Management 24 (6): 509-515.

Rindell, A., F.P. Santos, and A.P. de Lima. 2015. Two sides of a coin: Connecting corporate brand heritage to consumers' corporate image heritage. Journal of Brand Management 22 (5): 467-484.

Santos, F.P., M. Burghausen, and J.M.T. Balmer. 2016. Heritage branding orientation: The case of Ach. Brito and the dynamics between corporate and product heritage brands. Journal of Brand Management 23 (1): 67-88.

Schmeltz, L., and A.K. Kjeldsen. 2018. Co-creating polyphony or cacophony? A case study of a public organization's brand cocreation process and the challenge of orchestrating multiple internal voices. Journal of Brand Management.. https://doi.org/ 10.1057/s41262-018-0124-2.

Schmidt, H.J., and J. Redler. 2018. How diverse is corporate brand management research? Comparing schools of corporate brand management with approaches to corporate strategy. Journal of Product and Brand Management 27 (2): 185-202.

Schmitt, B.H., J. Brakus, and L. Zarantonello. 2015. The current state and future of brand experience. Journal of Brand Management 21 (9): 727-733.

Schroeder, J., J. Borgerson, and Z. Wu. 2015. A brand culture approach to Chinese cultural heritage brands. Journal of Brand Management 22 (3): 261-279.

Shah, P. 2015. Kill it or keep it?: The weak brand retain-or-discard decision in brand portfolio management. Journal of Brand Management 22 (2): 154-172.
Sinclair, R., and K.L. Keller. 2017. Brand value, accounting standards, and mergers and acquisitions: "The Moribund Effect". Journal of Brand Management 24 (2): 178-192.

Stuart, H.J. 2013. Positioning the corporate brand as a sustainable: Leadership de rigueur. Journal of Brand Management 20 (9): 793-799.

Joachim Kernstock is head of centre of competence for brand management in St. Gallen, Switzerland. $\mathrm{He}$ is an experienced corporate brand strategy advisor. He works with leading Swiss and European corporates and also with SME's. He has published leading publications about corporate brand management and brand behaviour in Germany and within international refereed journals. He lectures at the University of St. Gallen. Before this engagement, he was responsible for the Lufthansa corporate marketing and brand portfolio. Joachim has been co-editor of the Journal of Brand Management since 2012.

Shaun M. Powell is a member of the Faculty of Business at the University of Wollongong in Australia. He has published in a number of international refereed journals and has recently co-edited books on luxury brand management and corporate brand management alongside leading thought leaders in the field. He remains a member of several journal editorial boards and attends international academic, practitioner and industry-based summits, conferences and symposiums in his areas of expertise. Shaun has been co-editor of the Journal of Brand Management since 2012. 